\title{
Effects of the Shading Rate on the Electrical Parameters of CIGS-Based Solar Modules
}

\author{
El Hadji Abdoulaye Niass', Papa Touty Traore"1, Awa Dieye1, Oumar Absatou Niasse1, \\ Pierre Tavarez ${ }^{1}$, Nacire Mbengue ${ }^{1}$, Zakaria Makir ${ }^{2}$, Zouhair Sofiani², Bassirou Ba ${ }^{1}$ \\ ${ }^{1}$ Physics Department, Faculty of Science and Technology, University Cheikh Anta Diop, Dakar, Senegal \\ ${ }^{2}$ Physics Department, Faculty of Science and Technology of Mohmammadia, Laboratory Laboratory of Materials and Energy and \\ System Control, University Hassan II, Casablanca, Marocco \\ Email: papatoutytraore@gmail.com
}

How to cite this paper: Niass, E.H.A. Traore, P.T., Dieye, A., Niasse, O.A., Tavarez, P., Mbengue, N., Makir, Z., Sofiani, Z. and Ba, B. (2021) Effects of the Shading Rate on the Electrical Parameters of CIGS-Based Solar Modules. Energy and Power Engineering, 13, 483-491.

https://doi.org/10.4236/epe.2021.1312032

Received: October 21, 2021

Accepted: December 28, 2021

Published: December 31, 2021

Copyright $\odot 2021$ by author(s) and Scientific Research Publishing Inc. This work is licensed under the Creative Commons Attribution International License (CC BY 4.0).

http://creativecommons.org/licenses/by/4.0/

\begin{abstract}
The aim of this article is to study the effects of the shading rate on the electrical performance parameters of CIGS PV modules. The study concerns a new flexible CIGS type photovoltaic module with a power of $90 \mathrm{~W}$, manufactured by the company Shenzhen Shine Solar Co., Ltd. This module, reference SN-CIGS90, is tested under the initial conditions to ensure its correct operation and to determine the initial values of the electrical parameters before shading. After this characterization test, the module is exposed under the actual operating conditions of the Renewable Energies Study and Research Center (CERER), located in Dakar, then 4 types of shading are performed with the same mask: partial shading 25\% partial shading, 50\% partial shading, $75 \%$ partial shading, and $100 \%$ full shading. The variation rates obtained on the experimental values of the 4 types of shading carried out determine that the shading phenomenon constitutes a factor that influences negatively on the electrical parameters of a CIGS-based PV module. Indeed, for $25 \%$ of the surface of the shaded module, there is a reduction of $58.139 \%$ of the maximum power and of $60.507 \%$ of the efficiency and for shading of $100 \%$, the module loses $84.436 \%$ of its maximum power and $84.135 \%$ of its performance.
\end{abstract}

\section{Keywords}

Modulus, Shading Rate, Electrical Parameters, Mask

\section{Introduction}

When new, a PV module is characterized by its electrical parameters such as short-circuit current; the open-circuit voltage, efficiency and the maximum 
power it delivers. These data vary overtime when the module is exposed to sunlight with the actual operating conditions of the installation site [1].

This variation can be due to several factors, among which we can quote the shading. Studies have shown that the output power of photovoltaic panels is sometimes lowered due to the appearance of shadow on them [2] [3]. In one of their studies, Zaihidee et al. [4] showed that on only $2 \%$ of the shaded area of the module, the performance loss was $70 \%$.

Shadows can be caused by trees, buildings, but also by mounting structures of some modules on others, droppings falling on the modules as well as leaves from trees and others...

When a module is shaded in a series-connected module system, bypass diodes can prevent the shaded module from being reverse biased. If the bypass diodes open, the shaded module is indeed shorted. And if the bypass diodes fail or are ineffective, the shaded module may experience reverse bias stress, which is very dangerous for the module [5].

It has been observed that CIGS modules, subjected to the stresses of reverse polarizations, develop white characteristics similar to worms visible under the glass which have been associated with hot spots [6]. The presence of hot spots in CIGS modules is a key factor in the failure of these modules due to shading [7] [8].

The use of protective diodes to protect against power loss and reverse bias is difficult in thin-film modules [9].

In our study, we showed the impact of shading on the electrical parameters of CIGS-type photovoltaic modules installed in a Sahelian environment. The analysis of the various rates obtained on the experimental values of 4 types of shading is the object of this study.

\section{Experimental Study}

\subsection{Description of the Experimental Material}

1) The flexible CIGS module

To carry out this experimental study of the effect of the shading rate on the electrical parameters of CIGS-based solar modules, we bought a new flexible CIGS type module. Table 1 shows the construction data of the module.

Figure 1 shows the module in a new condition.

2) The measurement platform

The work was carried out on the site of the Center for Study and Research on Renewable Energies of the Cheikh Anta DIOP University of Dakar (CERER) where the flexible CIGS type module was exposed. The measurement platform also includes the electronic analyzer ESL-Solar 500 which is an electronic case specially designed for testing solar cells and modules of all technologies. It measures the short-circuit current, the open-circuit voltage, the maximum current, the maximum voltage, the form factor, the maximum power, the efficiency, the temperature of the module, the irradiation... All these functions are dis- 
played on the clear multifunction screen of a computer coupled to the suitcase. Figure 2 shows the device for experimental measurements.

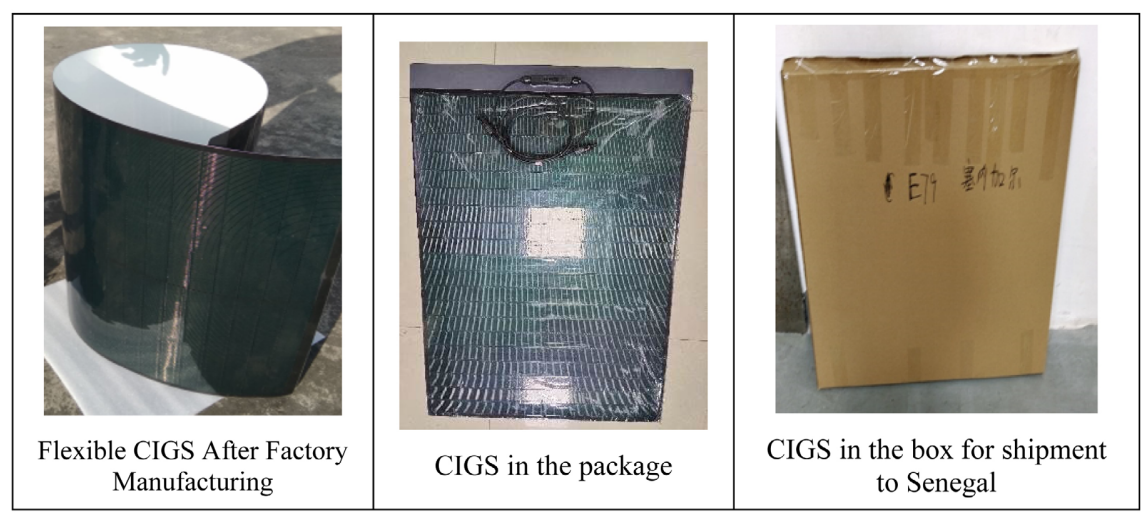

Figure 1. CIGS module in new condition.

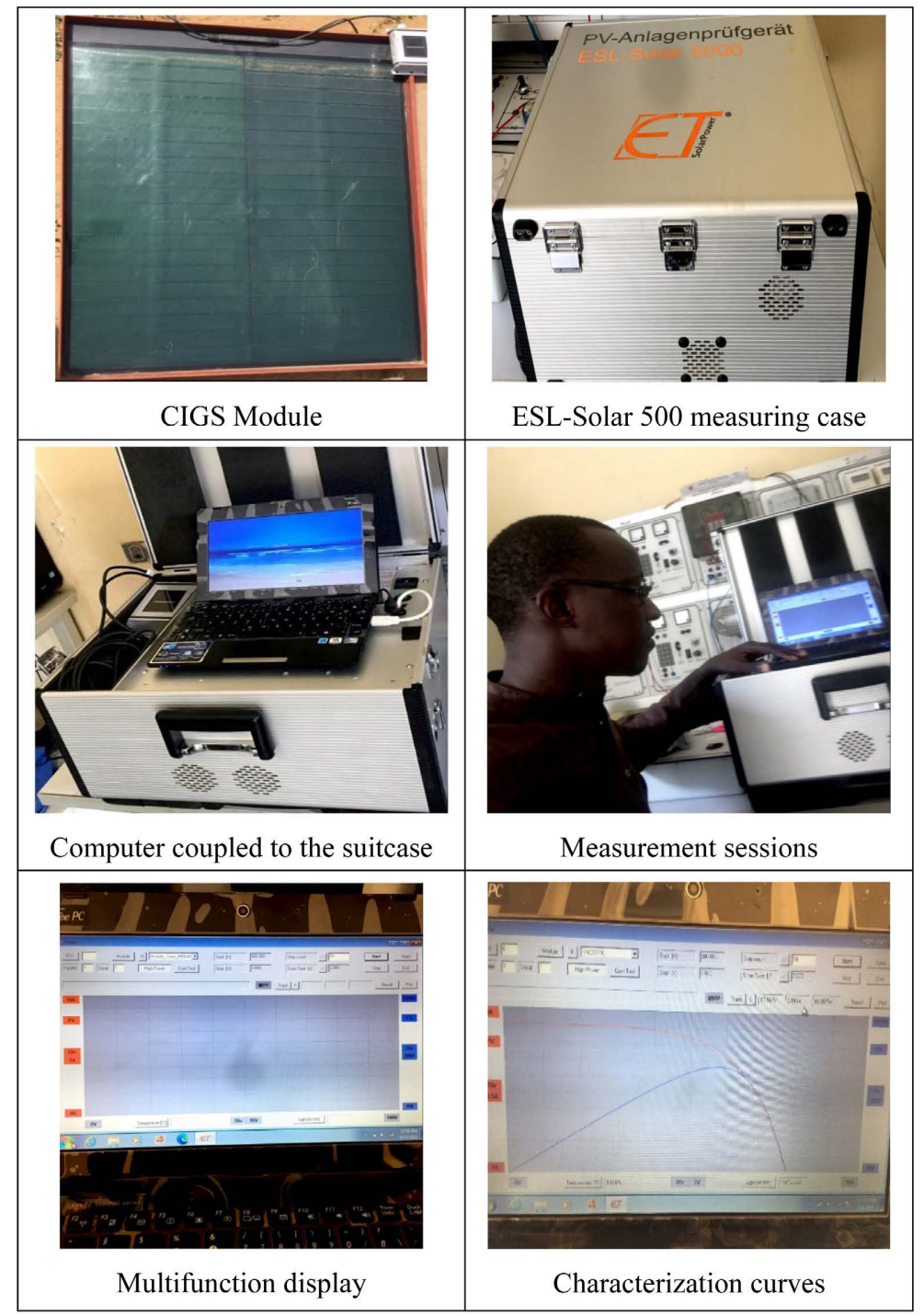

Figure 2. Characterization tests and determination of initial values. 
Table 1. Construction data of the module.

\begin{tabular}{cccccc}
\hline Technology & Reference & $V_{\text {co }}(\mathrm{V})$ & $I_{\text {cc }}(\mathrm{A})$ & $P_{\max }(\mathrm{W})$ & $\eta(\%)$ \\
\hline CIGS & SN-CIGS 90 & 4.890 & 25.600 & 90.00 & 14 \\
\hline
\end{tabular}

\subsection{Experimental study}

After this test, the module is exposed on the CERER site and underwent 4 types of shading:

- Partial shading at $25 \%$, corresponding to a quarter of the surface of the module.

- Partial shading at 50\%, corresponding to half of the surface of the module.

- Partial shade at $75 \%$, corresponding to three quarters of the surface of the module.

- Total shading at $100 \%$, corresponding to the total surface of the module.

Figure 3 illustrates this.

\section{Results and Discussions}

Using an "ESL-SOLAR-500" analyzer, we sought to determine the effect of the shading rate on the electrical performance parameters of the CIGS module. The study is carried out at the Renewable Energies Study and Research Center (CERER), located in Dakar. The results obtained are presented in Table 2.

In our experimental studies below, we need to determine the rates of absolute and relative variations between the initial parameters and those obtained after the study. For this, we used the following equations:

$$
\begin{gathered}
\text { TVA }=V_{F}-V_{I} \\
\text { TVR }=\frac{V_{F}-V_{I}}{V_{I}} \times 100
\end{gathered}
$$

VAT, the absolute rate of change, TVR, the relative rate of change;

$V_{F}$, the final value of the parameter and $V_{P}$ the initial value of the parameter.

Table 3 shows the results obtained as a function of the shading rate.

We observe in this study a strong decrease of all the electrical parameters which increases with the shading rate, except the open-circuit voltage $V_{c o}$, which presents a slight decrease.

Indeed, for $25 \%$ shading, the module loses $58.139 \%$ of its maximum power $\left(P_{\max }\right), 60.507 \%$ of its efficiency $(\eta), 35.035 \%$ of short-circuit current $\left(I_{s c}\right)$ and only $1.269 \%$ of the voltage open circuit $\left(V_{c o}\right)$. For $50 \%$ of the surface of the shaded module, the loss is $73.866 \%$ of $P_{\max }, 60.293 \%$ of $\eta, 39.648 \%$ of $I_{s c}$ and $4.612 \%$ of $V_{c o}$. For $75 \%$ of the surface of the shaded module, the loss is $82.153 \%$ of $P_{\max }, 75.352 \%$ of $\eta, 74.122 \%$ of $I_{s c}$ and $9.678 \% V_{c o}$. For total shading, the module loses $84.436 \%$ of its maximum power, $84.135 \%$ of its efficiency, $82.482 \%$ of short-circuit current and $11.086 \%$ of the voltage open circuit.

These results obtained only like all thin-film technologies, for which shading constitutes a phenomenon that severely reduces the efficiency of CIGS-based 
Table 2. The different electrical parameters obtained for the 4 types of shading.

\begin{tabular}{|c|c|c|c|c|c|}
\hline \multirow[t]{7}{*}{$\begin{array}{c}\text { Module } \\
(\mathrm{SN}-\mathrm{CIGS} 90)\end{array}$} & $\begin{array}{l}\text { Experimentals } \\
\text { Conditions }\end{array}$ & \multicolumn{4}{|c|}{$\begin{array}{ll}\text { - } & \text { Illuminance }\left(\mathrm{W} / \mathrm{m}^{2}\right) \text { 825: Initial measurement (before shading) } \\
\text { - } & \text { Illuminance }\left(\mathrm{W} / \mathrm{m}^{2}\right) \text { 837: First measurement (25\% shading) } \\
\text { - } & \text { Illuminance }\left(\mathrm{W} / \mathrm{m}^{2}\right) \text { 835: Second measurement (50\% shading) } \\
\text { - } & \text { Illuminance }\left(\mathrm{W} / \mathrm{m}^{2}\right) \text { 838: Third measurement ( } 75 \% \text { shading } \\
\text { - } & \text { Illuminance }\left(\mathrm{W} / \mathrm{m}^{2}\right) \text { 830: Fourth measurement ( } 100 \% \text { shading) } \\
\text { - } & \text { Temperature }\left({ }^{\circ} \mathrm{C}\right) \text { 57: Initial measurement (characterization test) } \\
\text { - } & \text { Temperature }\left({ }^{\circ} \mathrm{C}\right) \text { 52.9: First measurement ( } 25 \% \text { shading) } \\
\text { - } & \text { Temperature }\left({ }^{\circ} \mathrm{C}\right) \text { 55: Second measurement (50\% shading) } \\
\text { - } & \text { Temperature }\left({ }^{\circ} \mathrm{C}\right) \text { 50.5: Third measurement ( } 75 \% \text { shade) } \\
\text { - } & \text { Temperature }\left({ }^{\circ} \mathrm{C}\right) \text { 55.0: Fourth measurement ( } 100 \% \text { shading) }\end{array}$} \\
\hline & Parameters & $I_{c c}(\mathrm{~A})$ & $V_{o c}(\mathrm{~V})$ & $P_{\max }(\mathrm{W})$ & $\eta(\%)$ \\
\hline & Initial values before shading & 4.270 & 23.092 & 60.917 & 13.048 \\
\hline & Values obtained for $25 \%$ shade. & 2.774 & 22.799 & 25.500 & 5.153 \\
\hline & Values obtained for $50 \%$ shade. & 2.658 & 22.027 & 15.920 & 5.181 \\
\hline & Values obtained for $75 \%$ shade. & 1.105 & 21.685 & 10.872 & 3.216 \\
\hline & Values obtained for $100 \%$ shade. & 0.748 & 20.532 & 9.481 & 2.070 \\
\hline
\end{tabular}

Table 3. Results on the shaded module, (a) $25 \%$ shading, (b) $50 \%$ shading, (c) $75 \%$ shading, (d) $100 \%$ shading.

\begin{tabular}{|c|c|c|c|}
\hline Moduls & Parameters & The absolute rate of change & The relative rate of change \\
\hline & $P_{\max }(\mathrm{W})$ & -35.417 & $-58.139 \%$ \\
\hline (a) & $V_{o c}(\mathrm{~V})$ & -0.293 & $-1.269 \%$ \\
\hline \multirow[t]{3}{*}{$25 \%$ shading } & $I_{c c}(\mathrm{~A})$ & -1.496 & $-35.035 \%$ \\
\hline & $\eta(\%)$ & -7.895 & $-60.507 \%$ \\
\hline & $P_{\max }(\mathrm{W})$ & -44.997 & $-73.866 \%$ \\
\hline (b) & $V_{o c}(\mathrm{~V})$ & -1.065 & $4.612 \%$ \\
\hline \multirow[t]{3}{*}{$50 \%$ shading } & $I_{c c}(\mathrm{~A})$ & -1.693 & $-39.648 \%$ \\
\hline & $\eta(\%)$ & -7.867 & $-60.293 \%$ \\
\hline & $P_{\max }(\mathrm{W})$ & -50.045 & $-82.153 \%$ \\
\hline (c) & $V_{o c}(\mathrm{~V})$ & -2.235 & $-9.678 \%$ \\
\hline \multirow[t]{3}{*}{$75 \%$ shading } & $I_{c c}(\mathrm{~A})$ & -3.165 & $-74.122 \%$ \\
\hline & $\eta(\%)$ & -9.832 & $-75.352 \%$ \\
\hline & $P_{\max }(\mathrm{W})$ & -51436 & $-84.436 \%$ \\
\hline (d) & $V_{o c}(\mathrm{~V})$ & -2.560 & $-11.086 \%$ \\
\hline \multirow[t]{2}{*}{$100 \%$ shading } & $I_{c c}(\mathrm{~A})$ & -3.522 & $-82.482 \%$ \\
\hline & $\eta(\%)$ & -10.978 & $-84.135 \%$ \\
\hline
\end{tabular}

solar panels, even at new condition. This reduction depends on the area of the shaded module.

We have also observed that the loss of performance linked to the effect of shading depends on the nature and the thickness of the mask. 


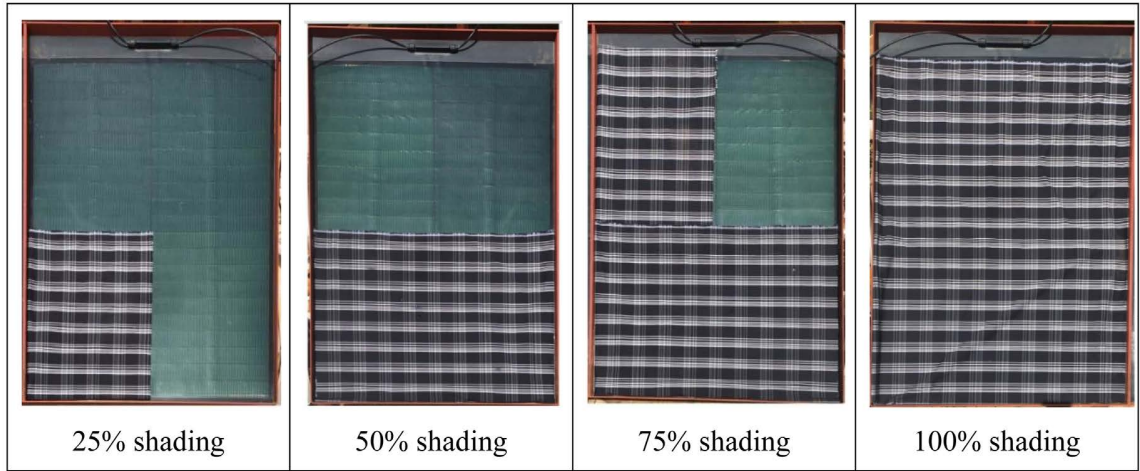

Figure 3. Different types of shading.

In fact, in these experimental research works, we also used masks of different types and thicknesses, to perform total shading on the same module under the same experimental conditions, and we obtained different results.

Figure 4 illustrates this.

The results obtained on the variation of the electrical parameters for each type of mask are shown in Table 4.

The analysis of these experimental results above allows us to say that the decrease in electrical parameters depends on the nature but also on the thickness of the mask used. Indeed, the loss of power is estimated at $39.910 \%$ for the total shading with a blue plastic tarpaulin as a mask, a little transparent, $84.436 \%$, for the total shading with a simple cotton fabric mask (75\% cotton) and at the end, $87.905 \%$ for total shading with a lab coat ( $100 \%$ cotton) used as a mask. Figure 5 shows the characteristic curves of the module as the function of shading rate.

The general shape of I (V) and P (V) curves shows that the shading causes significant deformations in I - V and P - V characteristics of CIGS-based photovoltaic modules. These deformations are more visible in the case of partial shading at $25 \%$ and $50 \%$ and we note in these two cases a non-uniformity of the curves.

We also observed a sharp decrease in the short-circuit current caused by shading. This reduction is obvious, insofar as the mask blocks the arrival of solar radiation on the surface of the module, which leads to a reduction in the charge carriers generated by the module and consequently a reduction in the short-circuit current depending on the module.

Studies have shown that for a cell with a high shunt resistance, the effect on the distortion of I - V characteristic will be less severe [10]. Another effect of shading is that of shifting the point of maximum power to lower voltage values. Indeed, the smallest shading rate (25\%) performed on the module, generates a power reduction of around $58.139 \%$ which is dissipated in the form of heat. In short, the shading effect can cause poor operation of the photovoltaic system, which is why the solar panels must be protected by bypass diodes and the system must be connected to an inverter following the maximum power point (MPP) in order to be able to carry out permanent monitoring of the system. 


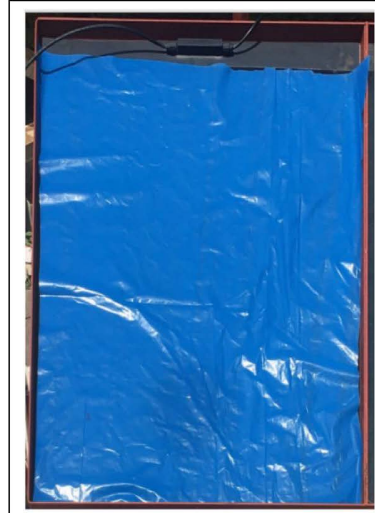

Full shade with plastic sheeting

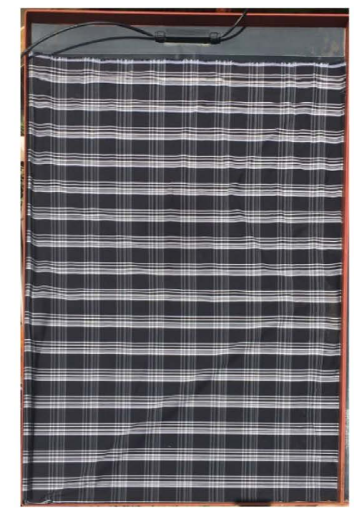

Full shade wit lightweight cotton fabric

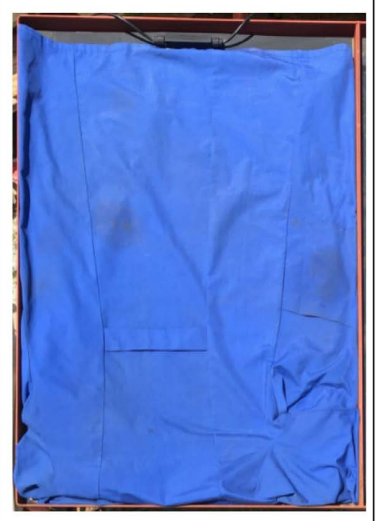

Full shade with a lab coat

Figure 4. Full shading with different masks.

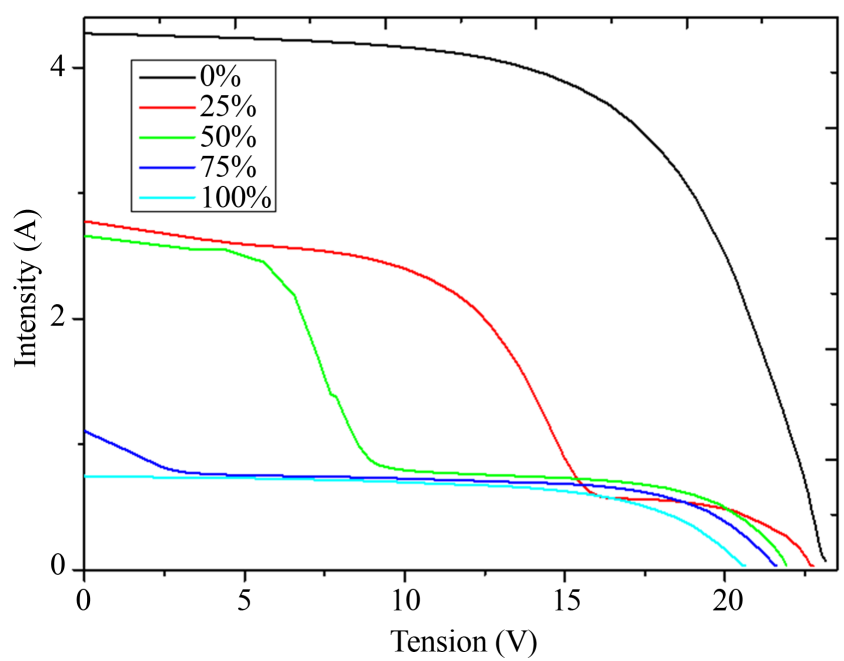

(a)

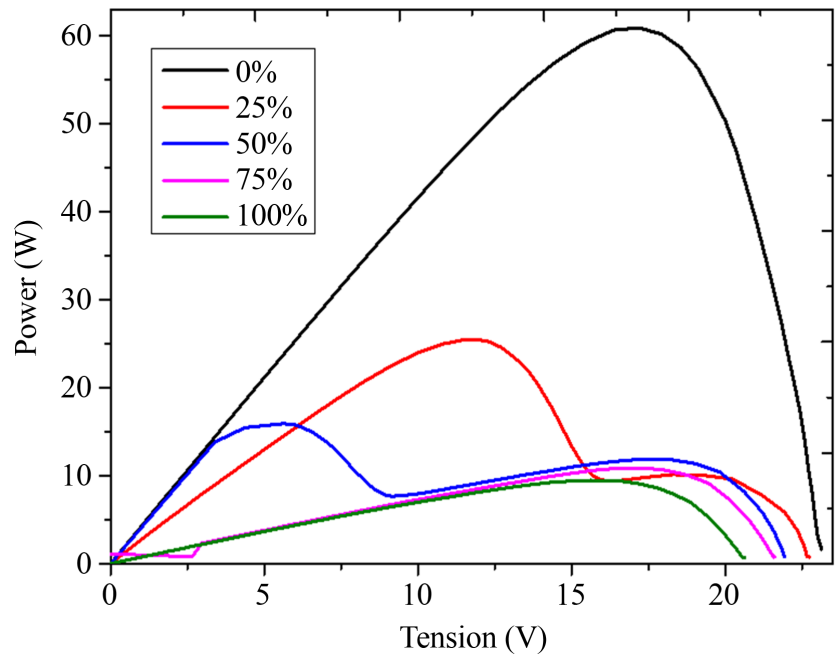

(b)

Figure 5. I - V and P - V characteristic curves of the module as a function of the shading rate, where: (a) represents $\mathrm{I}-\mathrm{V}$ and (b) represents $\mathrm{P}-\mathrm{V}$. 
Table 4. Results obtained for total shading with different masks.

\begin{tabular}{|c|c|c|c|c|}
\hline $\begin{array}{l}\text { Experimental } \\
\text { conditions }\end{array}$ & $\begin{array}{l}\text { - } \text { Illun } \\
\text { - Tem }\end{array}$ & $\begin{array}{l}\text { ation }(\mathrm{W} \\
\text { ature }\left({ }^{\circ} \mathrm{C}\right.\end{array}$ & $\begin{array}{l}\left.m^{2}\right) 830 \\
55:\end{array}$ & \\
\hline Parameters & $I_{\mathrm{cc}}(\mathrm{A})$ & $V_{\text {oc }}(\mathrm{V})$ & $P_{\max }(\mathrm{W})$ & $\eta(\%)$ \\
\hline Initial values before shading & 4.270 & 23.092 & 60.917 & 13.048 \\
\hline $\begin{array}{l}\text { Values obtained for total shading with } \\
\text { a slightly transparent plastic cover }\end{array}$ & 2.604 & 22.935 & 36.605 & 7.877 \\
\hline $\begin{array}{l}\text { Values obtained for full shade with } \\
\text { a single cotton fabric of ( } 75 \% \text { cotton) }\end{array}$ & 0.748 & 20.532 & 9.481 & 2.070 \\
\hline $\begin{array}{l}\text { Values obtained for total shade with } \\
\text { a lab coat ( } 100 \% \text { cotton })\end{array}$ & 0.680 & 20.669 & 7.368 & 1.618 \\
\hline
\end{tabular}

\section{Conclusion}

Our study focused on the analysis of variations in the electrical parameters of a CIGS-based photovoltaic module under shading conditions. The evolution of the electrical parameters describing the operation of the module as well as the I $\mathrm{V}$ and $\mathrm{P}-\mathrm{V}$ characteristics with the shading rate were obtained for four occultation configurations. The objective was to study the impact of the shading rate on the electrical parameters of the module in question. The data collected indicate that the shading causes a sharp decrease in the electrical parameters of the CIGS modules. Apart from the open-circuit voltage, which is not too much influenced by the shading phenomenon because it shows a slight decrease, all the other parameters show a strong decrease, the value of which increases with the percentage of the shaded area of the module but also the nature and thickness of the mask used.

\section{Conflicts of Interest}

The authors declare no conflicts of interest regarding the publication of this paper.

\section{References}

[1] Wohlgemuth, J., Cunningham, D., Nguyen, A.M. and Miller, J. (2005) Long Term Reliability of PV Modules. 20th European Photovoltaic Solar Energy Conference, Barcelona, Spain, 1942-1946.

[2] Mani, M. and Pillai, R. (2010) Impact of Dust on Solar Photovoltaic (PV) Performance: Research Status, Challenges and Recommendations. Renewable and Sustainable Energy Reviews, 14, 3124-3131. https://doi.org/10.1016/j.rser.2010.07.065

[3] Saidan, M., Albaali, A.G., Alasis, E. and Kaldellis, J.K. (2016) Experimental Study on the Effect of Dust Deposition on Solar Photovoltaic Panels in Desert Environment. Renew Energy, 92, 499-505. https://doi.org/10.1016/j.renene.2016.02.031

[4] Zaihidee, F.M., Mekhilef, S., Seyedmahmoudian, M. and Horan, B. (2016) Dust as an Unalterable Deteriorative Factor Affecting PV Panel's Efficiency: Why and How. Renewable and Sustainable Energy Reviews, 65, 1267-1278. https://doi.org/10.1016/j.rser.2016.06.068 
[5] Nardone, M., Dahal, S. and Waddle, J.M. (2016) Shading-Induced Failure in Thin-Film Photovoltaic Modules: Electrothermal Simulation with Nonuniformities. Solar Energy, 139, 381-388. https://doi.org/10.1016/j.solener.2016.10.006

[6] Lee, J.E., Bae, S., Oh, W., Park, H., Kim, S.M., Lee, D., Nam, J., Mo, C.B., Kim, D., Yang, J., Kang, Y., Lee, H.-s. and Kim, D. (2016) Investigation of Damage Caused by Partial Shading of CuInxGa $\mathrm{Cl}_{(1-\mathrm{x})} \mathrm{Se}_{2}$ Photovoltaic Modules with Bypass Diodes. Progress in Photovoltaics, 24, 1035-1043. https://doi.org/10.1002/pip.2738

[7] Puttnins, S., Jander, S., Wehrmann, A., Benndorf, G., Stlzel, M., Mller, A., von Wenckstern, H., Daume, F., Rahm, A. and Grundmann, M. (2014) Breakdown Characteristics of Flexible $\mathrm{Cu}(\mathrm{In}, \mathrm{Ga}) \mathrm{Se}_{2}$ Solar Cells. Solar Energy Materials and Solar Cells, 120, 506-511. https://doi.org/10.1016/j.solmat.2013.09.031

[8] Szaniawski, P., Lindahl, J., Trndahl, T., Zimmermann, U. and Edoff, M. (2013) Light-Enhanced Reverse Breakdown in $\mathrm{Cu}(\mathrm{In}, \mathrm{Ga}) \mathrm{Se}_{2}$ Solar Cells. Thin Solid Films, 535, 326-330. https://doi.org/10.1016/j.tsf.2012.09.022

[9] Dongaonkar, S., Deline, C. and Alam, M.A. (2013) Performance and Reliability Implications of Two-Dimensional Shading in Monolithic Thin-Film Photovoltaic Modules. IEEE Journal of Photovoltaics, 3, 1367-1375. https://doi.org/10.1109/JPHOTOV.2013.2270349

[10] Miyazaki, H., Mikami, R., Akira, Y. and Konogai, M. (2003) Cu(InGa)Se $e_{2}$ Thin Film Absorber with High Ga Contents and Its Application to the Solar Cells. Journal of Physics and Chemistry of Solids, 64, 2055-2058. https://doi.org/10.1016/S0022-3697(03)00204-X 